\title{
JURNAL ILMIAH
}

\section{INTERVENSI NON-FARMAKOLOGIS PEMENUHAN KEBUTUHAN PSIKOSOSIAL PADA LANSIA: SEBUAH KAJIAN LITERATUR}

\author{
Maria Komariah $^{1 *}$, Zulfa Syafiyah Pratiwi ${ }^{2}$, Hanny Budhiyani ${ }^{3}$, Andi Adithia ${ }^{4}$ \\ 1,2,3,4 Fakultas Keperawatan Universitas Padjadjaran, Bandung \\ Email: maria.komariah@gmail.com
}

\begin{abstract}
ABSTRAK
Perubahan fisik yang terjadi pada lansia erat kaitannya dengan perubahan psikososialnya. Pengaruh yang muncul akibat berbagai perubahan pada lansia tersebut jika tidak teratasi dengan baik, cenderung akan mempengaruhi kesehatan lansia secara menyeluruh. Tujuan kajian literatur ini adalah untuk mengidentifikasi intervensi untuk memenuhi kebutuhan psikososial pada lansia. Peneliti melakukan peninjauan dan pencarian di beberapa search engine seperti Pubmed dan EBSCO. Setelah dilakukan penyortiran dengan menggunakan keyword, kriteria inklusi dan eksklusi yang ditentukan, didapatkan empat artikel yang sesuai dan digunakan dalam studi literatur. Hasil dari kajian literatur ditemukan beberapa jenis intervensi non-farmakologi untuk memenuhi kebutuhan psikososial pada lansia, yaitu terapi horticultura, latihan fisik dan mendengarkan Al-Quran, kerja kelompok, dan intervensi latihan gerak tari.
\end{abstract}

Kata kunci: Intervensi, kebutuhan, lansia, psikososial

\section{ABSTRACT}

The physical changes that occur in the elderly are closely related to their psychosocial changes. The effects that arise due to various changes in the elderly, if not properly resolved, tend to affect the overall health of the elderly. The purpose of this literature review is to identify interventions to meet the psychosocial needs of the elderly. Researchers conducted the review and search on several search engines such as Pubmed, EBSCO. After sorting using the specified keywords, inclusion, and exclusion criteria, four articles were obtained that were appropriate and used in the literature study. The results of the literature review found several types of non-pharmacological interventions to meet the psychosocial needs of the elderly, namely horticultural therapy, physical exercise and listening to the Al-Qur'an, group work, and dance movement interventions.

Keywords: elderly, interventions, needs, psychosocial

\section{PENDAHULUAN}

Lansia adalah tahap akhir dalam proses kehidupan yang akan menimbulkan banyak penurunan dan perubahan fisik, psikologi, sosial, yang saling berhubungan satu sama lain sehingga berpotensi menimbulkan masalah kesehatan fisik maupun jiwa pada lansia. Pada masa lansia seseorang mengalami kemunduran fisik, mental, dan sosial sedikit demi sedikit sampai tidak dapat melakukan tugasnya seharihari sehingga masa tua bagi kebanyakan orang, masa tua merupakan hal yang 
kurang menyenangkan otak (Santoso, 2019).

Perubahan fisik yang terjadi pada lansia erat kaitannya dengan perubahan psikososialnya. Pengaruh yang muncul akibat berbagai perubahan pada lansia tersebut jika tidak teratasi dengan baik, cenderung akan mempengaruhi kesehatan lansia secara menyeluruh. Banyak orang yang dapat menikmati masa tua akan tetapi tidak sedikit pula yang mengalami sakit dan sampai meninggal tanpa dapat menikmati masa tua dengan bahagia. Setiap orang pasti ingin memiliki masa tua yang bahagia tetapi keinginan tidaklah selalu dapat menjadi nyata. Pada kehidupan nyata, banyak sekali lansialansia yang menjadi depresi, stress, dan berpenyakitan (Kurnianto, 2015).

Psikososial merupakan penggabungan dari dua aspek yaitu psiko dan sosial. Psiko mengarah kepada aspek internal individu seperti pikiran, perasaan, nilai, kepercayaan yang dianut individu dan sosial mengarah pada aspek eksternal yaitu hubungan antara individu dengan lingkungan sekitarnya.

Menurut Departemen Kesehatan RI secara harfiah psikososial adalah hubungan dinamis antara aspek psikologis dan sosial, dimana masingmasing saling berinteraksi dan mempengaruhi secara berkesinambungan. Kebutuhan psikososial adalah setiap perubahan dalam kehidupan individu, baik yang bersifat psikologik maupun sosial yang mempunyai pengaruh timbal balik. Masalah kejiwaan dan kemasyarakatan yang mempunyai pengaruh timbal balik, sebagai akibat terjadinya perubahan sosial dan atau gejolak sosial dalam masyarakat yang dapat menimbulkan gangguan jiwa (Depkes, 2011).
Menurut Harnanto dan Rahayu (2016) psikososial adalah setiap perubahan dalam kehidupan individu, baik yang bersifat psikologik maupun sosial yang mempunyai pengaruh timbal balik.

Menurut Erikson Istilah "psikososial" dalam kaitannya dalam perkembangan manusia berarti bahwa tahap-tahap kehidupan seseorang dari lahir samapai mati dibentuk oleh pengaruh-pengaruh sosial yang berinteraksi dengan suatu organisme yang menjadikan seseorang matang secara fisik dan psikologis.

Salah satu komponen kebutuhan psikosial adalah pengalaman kehilangan, kematian, berduka, dan penyakit terminal. Kondisi terminal adalah suatu proses yang progresif menuju kematian berjalan melalui suatu tahapan proses penurunan fisik, psikososial dan spiritual bagi individu (Harnanto \& Rahayu, 2016). Dalam hal ini dukungan psikossosial dari keluarga diharapkan menjadi kunci utama untuk kesejahteraan lansia. Sehingga kebutuhan psikososial pada lansia dapat teratasi dengan baik dari keluarga (Mulyati, Martiatuti, \& Rasha, 2018).

Pengetahuan perawat dan keluarga dalam pemenuhan kebutuhan psikososial dalam hal kualitas hidup lansia. Kajian literature ini bertujuan untuk meningkatkan pengetahuan perawat dan keluarga terhadap kebutuhan psikososial pada lansia untuk meningkatkan kualitas hidupnya.

\section{METODE PENELITIAN}

Pencarian artikel dilakukan dengan menggunakan search engine yaitu Pubmed dan EBSCO. Pencarian artikel dilakukan dengan menggunakan kata kunci sesuai dengan teknik PICO 
yaitu P (Patient, Population, Problem), I (Intervention), $\mathrm{C}$ (Comparison) dan $\mathrm{O}$

(Outcome). Berikut PICO yang Tabel 1. PICO

\begin{tabular}{ll}
\hline Komponen & \\
\hline $\mathrm{P}($ Patient, Population, Problem $)$ & Elderly \\
$\mathrm{I}($ Intervention $)$ & Psychosocial \\
$\mathrm{C}($ Comparison $)$ & - \\
$\mathrm{O}$ (Outcome $)$ & Psychosocial \\
\hline
\end{tabular}

Berdasarkan teknik tersebut maka dalam pencarian artikel bahasa inggris digunakan kata kunci: "elderly" AND "psychosocial”. Sedangkan kata kunci yang digunakan untuk mencari artikel dalam bahasa Indonesia adalah: "lansia" DAN "psikososial".

Tabel 2. Jumlah Artikel

\begin{tabular}{lllllll}
\hline Database & Kriteria & $\begin{array}{l}\text { Jumlah } \\
\text { Keseluruhan } \\
\text { Artikel }\end{array}$ & $\begin{array}{c}\text { Kriteria } \\
\text { Inklusi \& } \\
\text { Eksklusi }\end{array}$ & $\begin{array}{c}\text { Jumlah } \\
\text { artikel hasil } \\
\text { penyortiran }\end{array}$ & $\begin{array}{c}\text { Kriteria } \\
\text { Inklusi \& } \\
\text { Eksklusi }\end{array}$ & $\begin{array}{l}\text { Jumlah } \\
\text { Artikel } \\
\text { yang } \\
\text { dianalisis }\end{array}$ \\
\hline PubMed & $\begin{array}{l}\text { Elderly AND } \\
\text { psychosocial }\end{array}$ & 42.111 & $\begin{array}{l}10 \text { tahun } \\
\text { terakhir, } \\
\text { full text, } \\
\text { RCT }\end{array}$ & 1.076 & $\begin{array}{l}\text { Sesuai dengan } \\
\text { topik } \\
\text { penelitian }\end{array}$ & 3 \\
& & & $\begin{array}{l}10 \text { tahun } \\
\text { terakhir, } \\
\text { full text }\end{array}$ & 47 & $\begin{array}{l}\text { Sesuai dengan } \\
\text { topik } \\
\text { penelitian }\end{array}$ & 1 \\
\hline Ebsco & Elderly AND & 1.871 & & & \\
& psychosocial. & & & & & \\
\hline
\end{tabular}




\section{HASIL}

Tabel 3. Hasil Analisis Artikel

\begin{tabular}{|c|c|c|c|c|c|c|c|}
\hline No & $\begin{array}{l}\text { Judul Artikel } \\
\text { dan Penulis }\end{array}$ & Tempat & $\begin{array}{l}\text { Populasi, Sample, } \\
\text { Teknik Sampling }\end{array}$ & $\begin{array}{c}\text { Metode } \\
\text { Penelitian } \\
\text { dan Variabel } \\
\end{array}$ & Instrumen & Hasil & Intervensi \\
\hline 1 & $\begin{array}{l}\text { Effects of } \\
\text { Horticultural } \\
\text { Therapy on } \\
\text { Asian Older } \\
\text { Adults: A } \\
\text { Randomized } \\
\text { Controlled Trial } \\
\text { Penulis: Kheng } \\
\text { Siang Ted Ng et } \\
\text { al (2018) }\end{array}$ & Singapore & 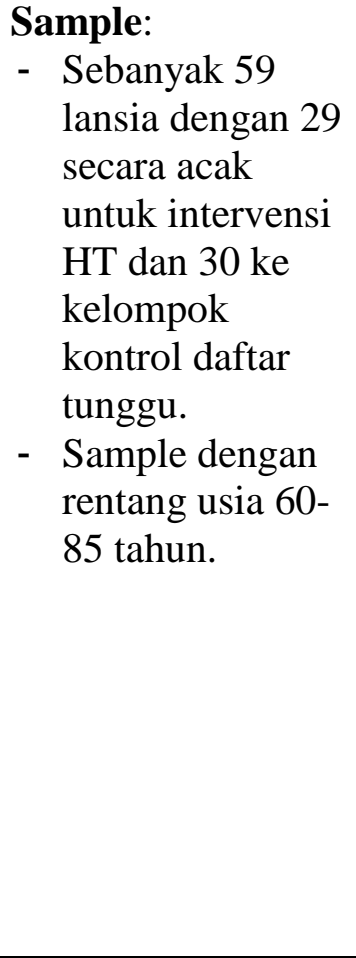 & $\begin{array}{l}\mathrm{RCT} \\
\text { (randomized } \\
\text { controlled } \\
\text { trial) }\end{array}$ & $\begin{array}{l}\text { 1. The } \\
\text { Montreal } \\
\text { Cognitive } \\
\text { Assessment } \\
\text { (MoCA) } \\
\text { untuk } \\
\text { mengukur } \\
\text { fungsi } \\
\text { kognitif para } \\
\text { peserta. } \\
\text { 2. Zung Self- } \\
\text { Rating } \\
\text { Depression } \\
\text { Scale (SDS) } \\
\text { 3. The Zung } \\
\text { Self-Rating } \\
\text { Anxiety } \\
\text { Scale (SAS) }\end{array}$ & $\begin{array}{l}\text { 1. Hasil dari } \\
\text { penelitian RCT ini } \\
\text { menunjukkan } \\
\text { bahwa terapi HT } \\
\text { (Horticultural) } \\
\text { berpotensi berguna } \\
\text { untuk mengurangi } \\
\text { peradangan dan } \\
\text { melindungi fungsi } \\
\text { saraf pada orang } \\
\text { dewasa lanjut usia } \\
\text { yang sehat dengan } \\
\text { mengurangi kadar } \\
\text { IL-6 plasma dan } \\
\text { mempertahankan } \\
\text { kadar plasma } \\
\text { CXCL12 (SDF- } \\
\text { 1 } \alpha \text { ), CXCL5 } \\
\text { (RANTES) dan } \\
\text { BDNF. }\end{array}$ & $\begin{array}{l}\text { 1.Intervensi terapi HT } \\
\text { (Horticultural) dirancang oleh } \\
\text { instruktur berpengalaman. Sesi } \\
\text { luar ruangan dilakukan di } \\
\text { beberapa taman / kebun } \\
\text { pilihan dan cagar alam di } \\
\text { Singapura. } \\
\text { Intervensi terdiri dari total } 15 \\
\text { sesi, dengan kegiatan mulai } \\
\text { dari berkebun dalam ruangan, } \\
\text { menanam, memelihara dan } \\
\text { memanen sayuran dan } \\
\text { tumbuhan hingga jalan-jalan } \\
\text { berpemandu di berbagai taman } \\
\text { dengan durasi setiap sesi } \\
\text { kurang lebih satu jam. Mereka } \\
\text { melakukan pada setiap minggu } \\
\text { selama tiga bulan, dan } \\
\text { kemudian setiap bulan selama } \\
\text { tiga bulan berikutnya. }\end{array}$ \\
\hline
\end{tabular}




\begin{tabular}{|c|c|c|c|c|c|c|c|}
\hline & & & & & & $\begin{array}{l}\text { 2. Meningkatkan } \\
\text { kesehatan fisik } \\
\text { dan mental }\end{array}$ & \\
\hline 2. & $\begin{array}{l}\text { Effects of } \\
\text { listening to Holy } \\
\text { Qur'an } \\
\text { recitation and } \\
\text { physical training } \\
\text { on dialysis } \\
\text { efficacy, } \\
\text { functional } \\
\text { capacity, and } \\
\text { psychosocial } \\
\text { outcomes in } \\
\text { elderly } \\
\text { patients } \\
\text { undergoing } \\
\text { haemodialysis } \\
\text { Penulis: } \\
\text { Bechir Frih et al } \\
\text { (2017) }\end{array}$ & $\begin{array}{l}\text { Tunisia, } \\
\text { Afkrika. }\end{array}$ & $\begin{array}{l}\text { Populasi: Lansia } \\
\text { Sampel: } \\
\text { - } 53 \text { lansia pria } \\
\text { yang menjalani } \\
\text { hemodialisa } \\
\text {-Semua partisipan } \\
\text { muslim }\end{array}$ & $\begin{array}{l}\mathrm{RCT} \\
\text { (randomized } \\
\text { controlled } \\
\text { trial) }\end{array}$ & $\begin{array}{l}\text { 1. Calculation } \\
\text { of dialysis } \\
\text { adequacy } \\
\text { (Kt/V) } \\
\text { 2. Functional } \\
\text { mobility } \\
\text { 3. The } \\
\text { Hospital } \\
\text { Anxiety and } \\
\text { Depression } \\
\text { Scale } \\
\text { (HADS) is a } \\
\text { self- } \\
\text { assessment } \\
\text { scale }\end{array}$ & $\begin{array}{l}\text { Penelitian ini } \\
\text { menunjukkan } \\
\text { bahwa } \\
\text { mendengarkan } \\
\text { pembacaan Al- } \\
\text { Qur'an yang } \\
\text { dikombinasikan } \\
\text { dengan pelatihan } \\
\text { ketahanan } \\
\text { ketahanan } \\
\text { interdialitik } \\
\text { menyebabkan } \\
\text { perbaikan kondisi } \\
\text { fisik dan kualitas } \\
\text { hidup dan } \\
\text { penurunan } \\
\text { kecemasan yang } \\
\text { besar di antara } \\
\text { pasien yang } \\
\text { menjalani } \\
\text { hemodialisis. }\end{array}$ & $\begin{array}{l}\text { 1. Latihan Fisik } \\
\text { Semua pasien menerima empat } \\
\text { sesi pelatihan interdialitik } \\
\text { setiap minggu selama } 24 \\
\text { minggu (total } 72 \text { sesi). } \\
\text { Pelatihan ketahanan terdiri dari } \\
\text { latihan penguatan dinamis. } \\
\text { Otot kuadrisep, otot dada, otot } \\
\text { trisep brachia, otot bisep } \\
\text { brachia, dan hamstring dilatih } \\
\text { secara multigym. Latihan } \\
\text { ketahanan terdiri dari latihan } \\
\text { ergocycle atau sesi jalan } \\
\text { treadmill } \\
\text { 2. Mendengarkan Al-Quran } \\
\text { Selama sesi hemodialisa, } \\
\text { pasien dalam kelompok } \\
\text { intervensi mendengarkan } \\
\text { pembacaan Al-Quran } \\
\text { menggunakan protokol yang } \\
\text { telah ditetapkan, sedangkan } \\
\text { kelompok kontrol hanya } \\
\text { menerima hemodialisa. Al- } \\
\text { Quran len Al-Qur'an lengkap } \\
\text { seluruhnya dibacakan oleh }\end{array}$ \\
\hline
\end{tabular}




\begin{tabular}{|c|c|c|c|c|c|c|c|}
\hline & & & & & & & $\begin{array}{l}\text { pembaca Al-Dosari, yang } \\
\text { membacanya dengan suara } \\
\text { yang menenangkan dan } \\
\text { menenangkan. Peserta } \\
\text { mendengarkan ayat-ayat } \\
\text { Alquran } \\
\text { tiga kali seminggu selama } 24 \\
\text { minggu, selama } 20 \text { menit } \\
\text { setiap kali (5 menit sebelum } \\
\text { dialisis dan berlanjut hingga } \\
15 \text { menit setelah dimulainya } \\
\text { dialisis). Metode ini } \\
\text { memungkinkan setiap pasien } \\
\text { untuk menyelesaikan Al- } \\
\text { Qur'an pada akhir periode } 24 \\
\text { minggu. Pembacaan Alquran } \\
\text { diputar melalui headphone } \\
\text { pada pemutar MP3 dan } \\
\text { volumenya disesuaikan dengan } \\
\text { kenyamanan pasien. }\end{array}$ \\
\hline 3. & $\begin{array}{l}\text { The Effects of } \\
\text { Group Work } \\
\text { With } \\
\text { Institutionalized } \\
\text { Elderly Persons } \\
\text { Penulis: }\end{array}$ & $\begin{array}{l}\text { Ankara, } \\
\text { Turkey }\end{array}$ & $\begin{array}{l}\text { Populasi: } 30 \text { lansia } \\
\text { Sampel : } 16 \text { dari } \\
\text { mereka menjadi } \\
\text { kelompok } \\
\text { perlakuan dan } 14 \\
\text { menjadi kelompok } \\
\text { kontrol. }\end{array}$ & $\begin{array}{l}\text { Quasi- } \\
\text { experimental }\end{array}$ & $\begin{array}{l}\text { 1. The } \\
\text { MOSES } \\
\text { 2. The } \\
\text { Geriatric } \\
\text { Depression } \\
\text { Scale- }\end{array}$ & $\begin{array}{l}\text { Lansia pada } \\
\text { kelompok } \\
\text { perlakuan } \\
\text { mengalami } \\
\text { penurunan depresi } \\
\text { dan meningkatnya } \\
\text { fungsi psikososial }\end{array}$ & $\begin{array}{l}\text { Group Work } \\
\text { Perlakuan diamati saling } \\
\text { mendukung dengan emosional, } \\
\text { bertukar nasihat tentang situasi } \\
\text { sulit. Empati dengan peserta lain } \\
\text { yang pernah atau telah } \\
\text { mengalami situasi serupa. }\end{array}$ \\
\hline
\end{tabular}




\begin{tabular}{|c|c|c|c|c|c|c|c|}
\hline & $\begin{array}{l}\text { Veli Duyan et al } \\
\text { (2017) }\end{array}$ & & $\begin{array}{l}\text { Tekning } \\
\text { sampling: } \\
\text { Purposive sampling }\end{array}$ & & $\begin{array}{l}\text { Short } \\
\text { (GDS-S) }\end{array}$ & $\begin{array}{l}\text { mereka. Intervensi } \\
\text { group work diikuti } \\
\text { dengan penurunan } \\
\text { tingkat depresi dan } \\
\text { meningkatnya } \\
\text { fungsi psikososial. }\end{array}$ & $\begin{array}{l}\text { Meningkatkan komunikatif, } \\
\text { keterampilan ekspresif, dan } \\
\text { asistif dari para peserta group } \\
\text { work. Selain itu, efektif untuk } \\
\text { mengembangkan hubungan, } \\
\text { mempertahankan persahabatan, } \\
\text { mendapatkan persepsi diri yang } \\
\text { lebih konstruktif, dan indera } \\
\text { yang memuaskan. }\end{array}$ \\
\hline 4. & $\begin{array}{l}\text { A 3-arm } \\
\text { randomized } \\
\text { controlled trial } \\
\text { on the effects of } \\
\text { dance } \\
\text { movement } \\
\text { intervention and } \\
\text { exercises on } \\
\text { elderly with } \\
\text { early dementia } \\
\text { Penulis: } \\
\text { Rainbow Tin } \\
\text { Hung Ho et al } \\
\text { (2015) }\end{array}$ & Cina & $\begin{array}{l}\text { Populasi: lansia } \\
\text { usia } 65 \text { sampai } 70 \\
\text { Sempel: } \mathbf{2 0 1} \\
\text { Teknik sampling }\end{array}$ & $R C T$ & & $\begin{array}{ll}\text { 1. } & \text { Intervensi } \\
\text { Menari } \\
\text { 2. Intervensi } \\
\text { berbasis } \\
\text { gerakan, } \\
\text { peregangan } \\
\text { dan latihan. }\end{array}$ & $\begin{array}{l}\text { penggunaan saliv- } \\
\text { ary cortisol akan menjelaskan } \\
\text { asosiasi pikiran-tubuh dan } \\
\text { memberikan bukti empiris } \\
\text { tentang efek tari intervensi } \\
\text { gerakan. Temuan studi ini akan } \\
\text { tidak hanya menunjang } \\
\text { keefektifan sebuah gerakan tari } \\
\text { intervensi berbasis, tetapi juga } \\
\text { akan memberikan model praktik } \\
\text { dan mendorong perkembangan } \\
\text { struktural yang serupa } \\
\text { program menyediakan populasi } \\
\text { lansia dengan dukungan } \\
\text { psikososial. }\end{array}$ \\
\hline
\end{tabular}


Dari hasil data ekstraksi didapatkan beberapa jenis tindakan keperawatan untuk pemenuhan kebutuhan psikososial pada lansia sebagai berikut:

\section{Terapi HT (Horticultural}

Terapi HT (Horticultural) dengan kegiatan mulai dari berkebun, menanam, memelihara dan memanen sayuran dan tumbuhan hingga jalan-jalan berpemandu di berbagai taman dengan durasi setiap sesi kurang lebih satu jam. Mereka melakukan pada setiap minggu selama tiga bulan, dan kemudian setiap bulan selama tiga bulan berikutnya.

\section{Latihan Fisik}

Pelatihan ketahanan terdiri dari latihan penguatan dinamis otot kuadrisep, otot dada, otot trisep brachia, otot bisep brachia, dan hamstring dilatih secara multigym. Latihan ketahanan terdiri dari latihan ergocycle atau sesi jalan treadmill.

\section{Mendengarkan Al-Quran}

Selama sesi hemodialisa, para pasien lansia dalam kelompok intervensi mendengarkan pembacaan Al-Quran menggunakan protokol yang telah ditetapkan, sedangkan kelompok kontrol hanya menerima hemodialisa. Al-Qur'an lengkap seluruhnya dibacakan oleh pembaca Al-Dosari, yang membacanya dengan suara yang menenangkan dan menenangkan. Peserta mendengarkan ayat-ayat Alquran tiga kali seminggu selama 24 minggu, selama 20 menit setiap kali (5 menit sebelum dialisis dan berlanjut hingga 15 menit setelah dimulainya dialisis). Metode ini memungkinkan setiap pasien untuk menyelesaikan Al-Qur'an pada akhir periode 24 minggu. Pembacaan Alquran diputar melalui headphone pada pemutar MP3 dan volumenya disesuaikan dengan kenyamanan pasien.

\section{Group Work}

Perlakuan diamati saling mendukung dengan emosional, bertukar nasihat tentang situasi sulit. Empati dengan peserta lain yang pernah atau telah mengalami situasi serupa. Meningkatkan komunikatif, keterampilan ekspresif, dan asistif dari para peserta group work. Selain itu, efektif untuk mengembangkan hubungan, mempertahankan persahabatan, mendapatkan persepsi diri yang lebih konstruktif, dan indera yang memuaskan.

\section{Intervensi Menari}

Intervensi berbasis gerakan, peregangan dan latihan. Temuan studi ini tidak hanya menunjang keefektifan sebuah gerakan berbasis intervensi tari, tetapi juga akan memberikan model praktik dan mendorong perkembangan struktural yang serupa program menyediakan populasi lansia dengan dukungan psikososial.

\section{PEMBAHASAN}

Lansia adalah tahap akhir dalam proses kehidupan yang akan terjadi banyak penurunan dan perubahan fisik, psikologi, sosial, yang saling berhubungan satu sama lain sehingga berpotensi menimbulkan masalah kesehatan fisik maupun jiwa pada lansia. Pada masa lansia seseorang mengalami kemunduran fisik, mental, dan sosial sedikit demi sedikit sampai tidak dapat melakukan tugasnya sehari-hari sehingga masa tua bagi kebanyakan orang, masa tua 
merupakan hal yang kurang menyenangkan otak (Santoso, 2019).

Maka dari pada itu lansia memerlukan asuhan atau intervensi untuk mengurangi masalah dimasa lansia. Menurut penelitian yang dilakukan oleh (Kheng., at al., 2019) dalam penelitiannya bahwa intervensi yang dapat diberikan yaitu terapi HT (Horticultural) terdiri dari total 15 sesi, dimulai dengan melakukan kegiatan berkebun, menanam, memelihara dan memanen sayuran serta tumbuhan hingga jalan-jalan dengan didampingi oleh pemandu di berbagai taman. Durasi dalam kegiatan ini memeiliki durasi setiap sesi kurang lebih satu jam. Kegiatan ini dilakukan setiap minggu selama tiga bulan, kemudian setiap bulan selama tiga bulan berikutnya. Hasil menunjukkan bahwa terapi HT (Horticultural) bermanfaat untuk mengurangi peradangan dan melindungi fungsi saraf pada lanjut usia yang sehat dengan mengurangi kadar IL-6 plasma dan mempertahankan kadar plasma.

Sedangkan menurut (Frih, et al., 2017) dengan meningkatkan kesehatan fisik dan mental dengan melakukan latihan fisik dan mendengarkan alquran. Hasil dalam penelitian ini yaitu dengan mendengarkan bacaan ayat Al-Qur'an yang dikombinasikan dengan pelatihan ketahanan interdialitik menghasilkan perbaikan kondisi fisik dan kualitas hidup serta penurunan kecemasan. Penelitian ini sejalan dengan penelitian yang dilakukan (Amanah \& Purnamasari, 2015) bahwa terapi Al-Qur'an berkaitan dengan keyakinana yang dianut oleh seseorang sehingga dapat memberikan kenyaman pada diri individu dalam menghadapi masalah psikososial yang dialaminya.

Adapun menurut (Duyan, at al., 2017) intervensi yang diberikan dengan melakukan terapi aktivitas kelompok dengan saling mengungkapkan perasaan yang sedang dialami kepada anggota kelompoknya. Pada penelitan tersebut didapatkan bahwa terdapat penurunan tingkat depresi dan meningkatnya fungsi psikososial. Hasil penelitian ini yaitu lansia dapat mengalami penurunan depresi dan meningkatnya fungsi psikososial mereka. Penelitian tersebut sejalan dengan hasil penelitian (Tandiayuk, 2013) bahwa terapi aktivitas kelompok pada lansia merupakan salah satu cara agar lansia berpartrisipasi dengan aktif dalam kegiatan-kegiatan yang dapat mempengaruhi terhadap psikososial yang dialami oleh lansia. Dalam hal ini terapi digunakan sebagai suatu asuhan untuk berinteraksi satu sama lain untuk membentuk suatu perilaku yang baik.

Lalu menurut (Cheung at, al., 2016) dengan memberikan intervensi melakukan kegiatan menari yang berbasis gerakan, peregangan dan latihan. Penelitian ini didapatkan hasil bahwa dengan melakukan kegaitan menari dapat mendorong perkembangan struktural terkait dukungan sosial. Penelitian tersebut sejalan dengan hasil penelitian yang dilakukan oleh (Kartikasari, 2016) kegiatan menari yang berbasis gerakan berhubungan dengan keterampilan psikomotorik dan kognitif yang mampu mengembangkan ekspresi dan persepsi sebagai suatu bentuk pengalihan dalam mengatasi masalah psikososial yang dialami lansia.

Dari beberapa intervensi tersebut diantaranya terapi HT (Horticultural) yaitu melakukan kegiatan berkebun, menanam, memelihara dan memanen sayuran serta tumbuhan hingga jalan-jalan dengan didampingi oleh pemandu di berbagai taman, meningkatkan kesehatan fisik dan mental dengan melakukan latihan fisik dan mendengarkan alquran, penurunan tingkat depresi dan meningkatnya fungsi psikososial, serta melakukan kegiatan menari yang berbasis gerakan, peregangan yang diberikan kepada lansia terbukti dapat meningkatkan kebutuhan psikologisnya. 
Peran perawat dalam mengatasi masalah psikososial pada lansia yaitu dengan memberikan terapi dan aktivitas yang dapat meningkatkan status mental dan keyakinan pada diri lansia, sehingga lansia mampu menjalani hidupnya dengan lebih baik dan tanpa memiliki pemikiran yang buruk

\section{KESIMPULAN}

Dari hasil pencarian beberapa jurnal yang sudah ditelaah, diantaranya terdapat berbagai jenis intervensi atau terapi yang dapat dilakukan untuk membantu mengatasi masalah psikologis pada lansia.

Intervensi yang telah didapatkan dari jurnal tersebut merupakan jenis intervensi non-farmakologi yaitu terapi horticultura, latihan fisik dan mendengarkan Al-Quran, kerja kelompok, dan intervensi latihan gerak tari. Intervensi berdasarkan jurnal yang sudah dianalisis memiliki hasil positif terhadap masalah psikososial lansia. Dengan adanya beberapa intervensi yang ditemukan dalam artikel dapat membantu perawat untuk menggunakan intervensi tersebut kepada pasien lansia. Perawat dalam mengimplementasikan intervensiintervensi tersebut harus menyesuaikan dengan keluhan dan kebutuhan dasar lansia terutama pada kebutuhan psikososial

\section{DAFTAR PUSTAKA}

Amanah, L., \& Purnamasari, S. E. (2015). Efektivitas Mendengarkan Bacaan Al-Quran terhadap Penurunan Tingkat Depresi pada Lansia. Insight: Jurnal Ilmiah Psikologi, 17(1), 11-28. http:// dx.doi.org/10.26486/psikologi.v17i1 .681

Aruma, D. E. O., \& Hanachor, D. M. E. (2017). Abraham Maslow's Hierarchy of Needs and Assessment of Needs in Community Development. International Journal of Development and Economic Sustainability, 5(7), 15-27.

Cheung, at al. (2018). Effects of horticultural therapy on asian older adults: A randomized controlled trial. International Journal of Environmental Research and Public Health, 15(8), 1-14. https://doi.org/10.3390/ijerph15081 705.

Duyan, V., at al. (2017). The effects of group work with institutionalized elderly persons. Research on Social Work Practice, 27(3), 366-374.

Frih, B., at al. (2017). Effects of listening to Holy Qur'an recitation and physical training on dialysis efficacy, functional capacity, and psychosocial outcomes in elderly patients undergoing haemodialysis. Libyan Journal of Medicine, 12(1). https://doi.org/10.1080/19932820.2 $\underline{017.1372032 .}$

Harnanto, A. M. \& Sunarsih Rahayu, (2016). Kebutuhan Dasar Manusia II. Jakarta: Kementrian Kesehatan RI.

Ho, R. T. H., Che Sunarsih ung, J. K. K., Chan, W. C., Cheung, I. K. M., \& Lam, L. C. W. (2015). A 3-arm randomized controlled trial on the effects of dance movement intervention and exercises on elderly with early dementia. $B M C$ geriatrics, 15(1), 1-8.

Kurnianto, D. (2015). Menjaga kesehatan di usia lanjut. Jorpres (Jurnal Olahraga Prestasi), 11(2). 
McLeod, S. (2020). Maslow's Hierarchy of Needs.

https://www.simplypsychology.org/ maslow.html.

Mousavi, S. H., \& Dargahi, H. (2013). Ethnic differences and motivation based on Maslow's theory on Iranian employees. Iranian Journal of Public Health, 42(5), 516-521.

Mulyati, M., Rasha, R., \& Martiatuti, K. (2018). Pengaruh dukungan sosial keluarga terhadap kualitas hidup dan kesejahteraan lansia. JKKP (Jurnal Kesejahteraan Keluarga dan Pendidikan), 5(1), 1-8.

Potter \& Perry. (2009). Buku Ajar Fundamental Keperawatan Konsep, Proses, dan Praktik Edisi 7. Jakarta: Salemba Medika.

Santoso, M. D. Y. (2019). Dukungan Sosial Meningkatkan Kualitas Hidup Lansia. Jurnal Kesehatan Mesencephalon, 5(1).

Sari, D. M. P., Lestari, C. Y. D., Putra, E. C., \& Nashori, F. (2018). Kualitas Hidup Lansia Ditinjau Dari Sabar Dan Dukungan Sosial. Jurnal Ilmiah Psikologi Terapan, 6(2), 131.

https://doi.org/10.22219/jipt.v6i2.53 41.

Sobur, A. (2016). Psikologi Umum. Bandung: CV Pustaka Setia.

Tandiayuk, M. S. (2013). Pengaruh Terapi Aktivitas Kelompok Stimulasi Sensori Terhadap Gangguan Psikososial Lanjut Usia Di Balai Penyantunan Lanjut Usia Senja Cerah Manado. Jurnal Ilmiah Perawat Manado (Juiperdo), 2(1), 25-29.

Wong. (2009). Buku Ajar: Keperawatan Pediatrik. Jakarta: EGC. 